\title{
Exploring the Barriers and Driving Factors in Implementing Building Information Modelling (BIM) in the Malaysian Construction Industry: A Preliminary Study
}

(Date received: 02.05.13/Date accepted: 20.12.2013)

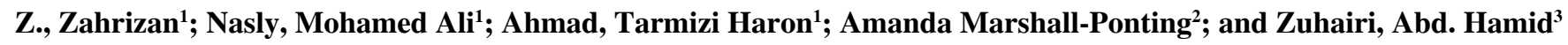 \\ ${ }^{1}$ Faculty of Civil Engineering and Earth Resources, Universiti Malaysia Pahang, Gambang, Kuantan \\ ${ }^{2}$ School of Build Environment, University of Salford Manchester, Salford, United Kingdom \\ ${ }^{3}$ Construction Research Institute of Malaysia (CREAM), \\ Construction Industry Development Board (CIDB), Cheras, Kuala Lumpur
}

E-mail: 'ahrizan@ump.edu.my; ${ }^{1}$ nasly@ump.edu.my; ${ }^{1}$ ahmadtarmizi@ump.edu.my;

${ }^{2}$ A.J.Marshall-Ponting@salford.ac.uk; ${ }^{3}$ zuhairi@cidb.gov.my

\begin{abstract}
In Malaysia, Building Information Modelling (BIM) has recently gained attraction from construction players and some of them have applied it to several projects. By utilising the BIM process, the construction players have the opportunity to plan, coordinate and design in an integrated approach. This is one of the many benefits that they could gain and resulting in increased productivity. Despite these benefits, the implementation of BIM in the Malaysian construction industry is still lagging behind Singapore, for instance. Thus, it warrants a study such as the present to determine what are the actual barriers that hamper its implementation and what are the driving factors that could enhance its pace of implementation in the Malaysian construction industry. In this study, a questionnaire survey based on Convenience Sampling Method was carried out to gather the possible barriers and driving factors for BIM implementation among the Malaysian construction players. Additionally, Relative Importance Indices (RII) were used to analyse the data obtained and to identify those barriers and driving factors for the implementation of BIM in this country. Consequently, results of this study revealed that the main barriers for implementing the BIM are: 1) Lack of knowledge about BIM, 2) Reluctance and/or no insistence shown by the Malaysian construction industry players (Clients, Contractors and Consultants alike) on the use or implementation of BIM. The driving factors, on the other hand, that could lead to the speeding up of the implementation of BIM are: 1) Support and enforcing the implementation of BIM by the Government, 2) promote BIM training program and 3) Initiatives of senior management of the related industry players. In conclusion, for successful wide spread application of BIM in Malaysia, a good push from the government alone is far from enough. All other construction industry players mentioned must assume their roles well in promoting the use of BIM in their construction projects.
\end{abstract}

Keywords: Building Information Modelling, BIM, Malaysian Construction Industry, Barriers, Driving Factors

\subsection{INTRODUCTION}

In Malaysia, the construction industry has been identified as an area that plays an important part in contributing to the Malaysian economy and contributes to approximately 3 to 5 percent of the Gross Domestic Product (GDP) annually [1]. Although the Malaysian construction industry plays a significant role contributing to the growth of Malaysia's economy, in the era of globalisation the Malaysian construction industry needs to evolve. The Malaysian construction industry must upgrade the current construction approach, whether in terms of practice, management or technology in order to be globally competitive because since the 1960's, construction industry has not transformed much in terms of technology or construction approach and still depends on traditional approaches and relies heavily on foreign labour [1 and 2]. 
In order to improve the traditional approach in the construction industry, Information Technology/ Information System (IT/IS) can be utilised to increase the productivities and transforms the Malaysian construction industry. Researchers [3, 4 and 5] have discussed the benefits of IT/IS applications. The benefits that could be gained by implementing IT/IS are enhancing the communication between parties, assisting in the decision making process, sharing updated information and accessing the information with ease [3, 4 and 5]. Realising these benefits, the government of Malaysia has been promoting and pushing the industry to adopt and utilise IT/ IS in order to achieve the developed country status by the year 2020 [6]. Despite the numerous benefits that could be gained by the construction industry, Stewart \& Mohamed [7] found that the construction industry in Malaysia still lags behind other industries in terms of implementing IT/ IS. This happens because the return in IT investments does not seem to be attractive. There are numerous factors to this and the objective of this paper is to explore the barriers and the driving factors that could contribute to implementing the new information technology especially Building Information Modelling (BIM) in the Malaysian construction industry.

\subsection{BUILDING INFORMATION MODELLING (BIM): AN OVERVIEW}

BIM can be viewed as a combination of advanced process and technology that offers a platform for collaboration between different parties in the construction project by exploiting the uses of Information Technology (IT). In the Malaysian construction industry, many construction players regard BIM as a new technology because it is not widely used. Traditionally, a 2D design that has been approved for construction will be checked manually. This method will consume time especially for complex designs. This traditional method involves manually checking for discrepancies in designs depending on the complexity of the designs. BIM can be referred as the process of creating and using 3D parametric computer-aided-design (CAD) technologies for design that allows the exchanges of information within a construction project team in a digital format $[8,9,10$ and 11]. This model can be passed digitally between consultants in the construction projects and the more important thing is that the model that is created using BIM has a pool of information and is enabled with clash detection software to ensure coordination [12]. This approach is not only faster, but can reduce the chance of human error to a minimum. This model can be passed to the contractor for estimating and planning the construction projects. In general, BIM can be viewed as a single respiratory system that supplies and receives any information in digital form related to construction projects.

\subsection{THE CHALLENGES IN IMPLEMENTING BUILDING INFORMATION MODELLING (BIM)}

There are many benefits that BIM can offer to the Malaysian construction industry, especially in enhancing the communication between different parties in construction projects. BIM is able to streamline and aids clear communication between client, consultant and contractor in construction projects by providing a single respiratory system for exchanging digital information in one or more agreed format. Khanzode \& Fisher [13] and Azhar et al. [14] believe that, this approach can reduce errors associated with inconsistent and uncoordinated project documents because BIM is capable of carrying information which are related to the building either its physical or functional characteristics. Furthermore, Kymmell [12] and Taylor \& Bernstein [11] believed that visualisation is one of the benefits gained when implementing BIM. The visualisation could help parties that are involved in the construction projects to gain better understanding of what they construct by creating detailed $3 \mathrm{D}$ view. Kymmell [12] added that one of the critical tasks in Mechanical, Electrical and Plumbing (MEP) design is clash detection and without having good visualisation tools, this task will consume time. Traditionally, in 2D drawing, clash detection process is done by overlaying 2D plan drawings to visualize the location of the system components in 3D space. However, by the exploitations of 3D parametric modelling between architect and structural engineer, this task can be done within a short time and is more accurate compared to traditional method. Other benefits that are gained by the utilisation of BIM are in terms of cost estimating and planning and scheduling when the information on BIM incorporated time and cost. In terms of cost estimating, BIM can facilitate quantity surveyor quantifying the cost and the material of the projects in shorter time which can be reduced up to $80 \%$ compared to traditional methods [14].

Despite the numerous benefits from the utilisation of BIM, review of literature also has identified the factors impeded the pace in implementing BIM in construction industry. Griffith et al. [15], O'Brien [16] and Whyte \& Bouchlaghem [17] believe that, the failure to implement new information technology (IT) in construction industry happens because of technical issues rather than social issues such as lack of technical expertise, the complexity 
of the system and lack of support system. However, Ruikar et al. [18] and Rojas \& Locsin [19] have a different view where they believe that people also play a part as the major barrier to implementing new IT in the construction industry. Martinko et al. [20] added that, the failure in changing people behaviour to handle new tools is the most prominent factor of why people are reluctant to adopt new technology. A survey done by Khemlani [21] revealed that the primary obstacles in implementing BIM is the resistance from employees who are reluctant to learn something new and challenges because of their beliefs and complacency with current status.

Meanwhile, Stephenson, P. \& Blaza, S. [22] and Love et al. [23] added, besides the factors of technology and people, the failure in implementing new technology is because of organisational problems. Some organisations are reluctant to change their business process because they are afraid that by changing their business process, it involves cost and jeopardises their established process because they cannot accept the uncertainty. Some people in that organisation feel that the technology will take over their roles and feel anxiety towards changes especially when new technology is involved and this happens because not many managers understand how to manage technological change. Many organisations believe that implementing BIM will affect their established business processes because implementing new technology will reshape their business processes and during this process, productivity will suffer because the transition process from fragmented to collaborative in nature will put the project outcomes and clients' expectations at risk [24].

To reduce the resistance from people to change, support from top management is very crucial [25] because during the migration to a new technology, the role of top management is very important to formulate the strategies and direction of the organisation in adopting new technology. This action shows the commitment of the organisation in adopting new technology and it will motivate their workers to implement new technology. Motivation of the organisation is one of the approaches to reduce the resistance from people. Motivation by the organisation could be one of the factors to build up selfconfidence to motivate individuals to use IT applications [16]. According to Stewart \& Mohamed [7] lack of knowledge and skill in using the new technology could lead to a hindrance of implementing new technology besides contributing to low self-confidence, therefore, a proper training provided by the organisation could reduce the resistance from people in the implementation. Training is one of the factors that could increase the pace in adopting new IT, but according to Eastman et al. [9], it is hard to guarantee that each person participating in the organisation has the required technology and skill, therefore, the organisation could establish a technical support group to cater these problems and to solve any problems that arise. This technical support group could disseminate their knowledge among the staff within an organisation and this activity could spread the spirit of knowledge sharing among them. Support from the authority also plays a significant role to promote the implementation of new IT. The authority could come out with an interactive package to any construction players who are willing to implement new IT [26; 21 and 27].

On top of cost, compatibility and complexity of the technology are also the factors that influence the adoption of new technology. Cost is a more subjective issue because it requires external factors such as regulations imposed by the government or clients. To increase the pace of adoption of new IT, higher compatibility and more user-friendly technology are the characteristics that the technology must have [28] because, it is easy for people to accept and use new technology if they are familiar with it. Besides, the time required for training can be reduced.

\subsection{METHODOLOGY}

In this study, an exploratory survey was used to discover and identify the relative importance of the barriers and the driven factors in implementing Building Information Modelling (BIM) in the Malaysian construction industry from the perception of clients, consultants and contractors. The survey questionnaire consists of three sections. The first section was to identify the respondents' profile. The second section of the questionnaire focused on the barriers factors in implementing BIM and the last section of the questionnaire was designed to identify the relative importance of the driving factors in implementing BIM.

In order to identify the relative importance of the barriers in implementing BIM, there was a total of 15 variables used while to identify the relative importance of the driving factors in implementing BIM, there was a total of 19 variables used and these variables were grouped into two categories: External Push and Internal Push. All these variables were selected from the literature. The respondents were asked to select their choices through open-ended questions by ticking a column of the relative importance of each of the question. A five-point Likert scale ranging from 1 which represented the least important to 5 which represented the most important was being used to capture the importance of the barriers and the driving factors in implementing Building Information Modelling (BIM) in the Malaysian construction industry. 
Convenience sampling method was used although this approach has its potential for bias. However, after considering that this is a preliminary study, convenience sampling was considered appropriate [29]. The sample's addresses were obtained from the company which registered with Construction Industry and Development Board (CIDB), a board of architects and engineers. The questionnaire was distributed via email to the 150 potential respondents at all levels in their organisations. Out of the 150 potential respondents, 50 sets of questionnaire were sent to clients, 50 sets to contractors and 50 set to consultants.

As shown in Table 1, out of the 150 questionnaires that were sent, 48 firms responded, thus, giving a response rate of $32 \%$. The response rate was considered average and acceptable because according to Frohlich [30], the normal average response rates for an organisational survey are about 30 to 40 percent since the middle of 1990 . Therefore, considering that this is a preliminary study, the response rate gathered from the clients, contractors and consultants which was $32 \%$ was considered appropriate.

The low response from the respondents happened due to their unawareness or they did not know of the existence or the term, BIM, especially for clients (response rate of $8 \%$ ) and contractors (response rate of $14 \%$ ).

Table 1: Respondents' Profile and Response Rate

\begin{tabular}{lccc}
\hline Respondents & $\begin{array}{c}\text { Questionnaire } \\
\text { distributed }\end{array}$ & $\begin{array}{c}\text { Responses } \\
\text { returned }\end{array}$ & $\begin{array}{c}\text { Percentage } \\
\text { of } \\
\text { responses }\end{array}$ \\
\hline Clients & 50 & 4 & $8 \%$ \\
Consultants & 50 & 37 & $74 \%$ \\
Contractors & 50 & 7 & $14 \%$ \\
\hline TOTAL & $\mathbf{1 5 0}$ & $\mathbf{4 8}$ & $\mathbf{3 2 \%}$ \\
\hline
\end{tabular}

\subsection{Method of Data Analysis}

The RII was calculated using the following formula:

$$
\mathrm{RII}=\frac{\sum \mathrm{P} i \mathrm{U} i}{\mathrm{~N}(n)}
$$

Where:

RII $=$ Relative Importance Indices

$\mathrm{P} i=$ Respondents' rating

$\mathrm{U} i=$ Number of respondents placing an identical weighting/rating

$\mathrm{N}=$ Sample size

$n=$ The highest attainable score (in this study $n$ is 5)

The value for RII ranges from 0 to 1 and the factors which scored the highest value of RII are the most important factors.

\subsection{FINDINGS AND DISCUSSION}

\subsection{Barriers in Implementing Building Information Modelling (BIM)}

Table 2 illustrates the relative importance indices and the rank for factors that hinder the implementation of BIM in the Malaysian construction industry by all respondents. From Table 2, the top five most important factors that hinder the implementation of BIM are (1) Lack of knowledge about BIM (RII = 0.950), (2) Clients do not request/enforce BIM (RII = 0.950), (3) Reluctance from clients, contractors or consultants to implement BIM (RII $=0.875)$, (4) BIM is not required by other team members $(\mathrm{RII}=0.838)$ and (5) Lack of data of Return on Investment of BIM (RII = 0.833).

Lack of knowledge about BIM could contribute to the resistance in implementing BIM because in the construction industry it involves various parties. Without significant knowledge about BIM, each party is reluctant to use BIM because they believe that new technology such as BIM technology is difficult to learn and could increase the operating cost. The lack of knowledge about BIM in terms of benefit to the operation and maintenance phase in the project's life cycle has a significant role on why clients, consultants, contractors and others parties that are involved in construction projects are reluctant to use BIM in their construction projects. In addition, lack of measurable data to measure the benefits and return from the investments in information technologies also plays a major role to their reluctance.

On the other hand, the three least important factors that could hinder the implementation of BIM are (1) BIM is too expensive (RII $=0.592$ ), (2) Lack of training of BIM software (RII $=0.608)$ and (3) BIM lacks features or flexibility to create a building model/drawing (RII $=0.650$ ). For the weakest factors, the respondents believe that the cost to purchase the BIM technology is not so expensive compared to the benefits that can be gained by utilising the BIM technology. On top of that, the respondents do not believe that BIM technology is lacking the flexibility to create a building model/drawing compared to the traditional 3 dimensional modelling (3D) such as AutoCAD. They found out that creating a 3D model is easier using BIM technology compared to the traditional 3D [8]. The respondents also believed that in the Malaysian construction industry, organisations are willing to send their staff to undergo related training in order to enhance their knowledge and skills, therefore, lacking in BIM training is not a factor that could hinder the implementation of BIM in the Malaysian construction industry. 
Table 2: Rank for Factors of Barriers

\begin{tabular}{|c|c|c|c|c|}
\hline & Factors why BIM is not being implemented in Malaysia & RII & Overall Rank & SD \\
\hline 1 & Lack of knowledge about BIM & 0.950 & 1 & 0.437595 \\
\hline 2 & Existing CAD system fulfils our need to design and draft & 0.804 & 8 & 0.668106 \\
\hline 3 & BIM is too expensive & 0.592 & 15 & 0.988408 \\
\hline 4 & Lack of training on BIM software & 0.608 & 14 & 0.898186 \\
\hline 5 & $\begin{array}{l}\text { BIM does not reduce the time used on drafting compared } \\
\text { with the current drawing approach }\end{array}$ & 0.650 & 12 & 0.668437 \\
\hline 6 & $\begin{array}{l}\text { BIM lacks features or flexibility to create a building model/ } \\
\text { drawing }\end{array}$ & 0.650 & 13 & 0.437595 \\
\hline 7 & Clients do not request/enforce BIM & 0.950 & 2 & 0.437595 \\
\hline 8 & BIM is not required by other team members & 0.838 & 4 & 0.733869 \\
\hline 9 & Application of BIM will affect the current process practice & 0.779 & 9 & 0.831292 \\
\hline 10 & Application of BIM will affect the current productivity & 0.779 & 10 & 0.831292 \\
\hline 11 & Legal or contract issue & 0.817 & 6 & 0.918679 \\
\hline 12 & Lack of working procedures and standards & 0.675 & 11 & 0.866025 \\
\hline 13 & $\begin{array}{l}\text { Reluctance from Client, Contractors or Consultant to } \\
\text { implement BIM }\end{array}$ & 0.875 & 3 & 0.761438 \\
\hline 14 & Lack of data of Return on Investment of BIM & 0.833 & 5 & 0.753244 \\
\hline 15 & Software related (i.e.: ease of use) & 0.808 & 7 & 0.988408 \\
\hline
\end{tabular}

\subsection{Driving Factors in Implementing Building Information Modelling (BIM)}

Table 3 shows a summary of the relative importance indices and the rank of the variables that could increase the pace of implementing BIM identified by the respondents. Table 3 also shows the relative importance indices of the categories that could increase the pace of implementing BIM. From Table 3, it can be found that the top ten most important factors that could increase the pace of implementing BIM are:

1) Support and enforcement in the implementation of BIM by the government $(\mathrm{RII}=0.950)$

2) BIM training program $(\mathrm{RII}=0.950)$

3) Leadership of senior management $(\mathrm{RII}=0.925)$

4) Provide a grant scheme for training BIM $(\mathrm{RII}=0.905)$

5) Promotion and awareness road show about BIM $(\mathrm{RII}=0.892)$

6) Collaboration with universities (Research collaboration and curriculum design for students) $(\mathrm{RII}=0.879)$

7) Incentive given by client such as tax reduction $(\mathrm{RII}=0.842)$

8) Outsourcing BIM specialist $(\mathrm{RII}=0.842)$

9) Technical support $(\mathrm{RII}=0.800)$
10) Clients demand the application of BIM in their project $(\mathrm{RII}=0.792)$

From the different categories of the factors that could increase the pace of implementation of BIM in the Malaysian construction industry, the respondents generally agreed that External Push $(\mathrm{RII}=0.805)$ has a more significant role to speed up the pace of implementation of BIM compared to the Internal Push $(\mathrm{RII}=0.755)$.

The most important factors that could be the driving factors in implementing BIM in the Malaysian construction industry are 1) Support and enforcement in the implementation of BIM by the Government and 2) BIM training program where both scored RII = 0.950. This indicates that in the Malaysian construction industry, government push is a must to implementing new approaches. Having a strong support from the government is vital and without the enforcement from the government in the implementation of BIM in the Malaysian construction industry, it will be slow or stagnant. Other countries like the United Kingdom (UK), Australia, Hong Kong and Singapore have implemented the use of BIM in their construction industry through their governments. In the UK for instance, the government is mandating BIM; Australia is supporting BIM, Singapore enforces the use of BIM as part of their policy and terms of contract and Hong Kong is assisting BIM [26, 21 and 27]. 
Table 3: Rank of Driving Factors

\begin{tabular}{|c|c|c|c|c|c|}
\hline & $\begin{array}{l}\text { Factors that could increase the pace of } \\
\text { implementing BIM in Malaysia }\end{array}$ & RII & Overall Rank & $\begin{array}{c}\text { Rank in } \\
\text { Group }\end{array}$ & SD \\
\hline & External Push & 0.805 & & & \\
\hline 1 & Clients willing to pay extra for BIM implementation & 0.488 & 19 & 9 & 0.711793 \\
\hline 2 & Promotion and awareness road show about BIM & 0.892 & 5 & 3 & 0.824062 \\
\hline 3 & Incentive given by client such as a tax reduction & 0.842 & 7 & 5 & 0.92157 \\
\hline 4 & Provide a grant scheme for BIM training & 0.904 & 4 & 2 & 0.850271 \\
\hline 5 & $\begin{array}{l}\text { Support and enforcement in the implementation of } \\
\text { BIM by the government }\end{array}$ & 0.950 & 1 & 1 & 0.437595 \\
\hline 6 & Clients provide pilot project for BIM & 0.763 & 12 & 7 & 0.981884 \\
\hline 7 & $\begin{array}{l}\text { Collaboration with universities (Research } \\
\text { collaboration and curriculum design for students) }\end{array}$ & 0.879 & 6 & 4 & 0.916505 \\
\hline 8 & $\begin{array}{l}\text { Clients demand the application of BIM in their } \\
\text { project }\end{array}$ & 0.792 & 10 & 6 & 0.797825 \\
\hline \multirow[t]{2}{*}{9} & BIM required by other project team members & 0.733 & 13 & 8 & 0.952786 \\
\hline & Internal Push & 0.775 & & & \\
\hline 1 & $\begin{array}{l}\text { Development of BIM department within an } \\
\text { organisation to monitor the application of BIM }\end{array}$ & 0.700 & 16 & 8 & 0.989305 \\
\hline 2 & Require/hire BIM specialist & 0.721 & 15 & 7 & 0.983688 \\
\hline 3 & Requirement for staff to be BIM competent & 0.608 & 18 & 10 & 0.742576 \\
\hline 4 & Outsourcing BIM specialist & 0.842 & 8 & 3 & 0.92157 \\
\hline 5 & An organisational structure that supports BIM & 0.792 & 11 & 5 & 0.797825 \\
\hline 6 & Standardise work procedure for BIM & 0.733 & 14 & 6 & 0.952786 \\
\hline 7 & Technical support & 0.800 & 9 & 4 & 0.71459 \\
\hline 8 & BIM training program & 0.950 & 2 & 1 & 0.437595 \\
\hline 9 & Continuous investment in BIM & 0.683 & 17 & 9 & 0.646869 \\
\hline 10 & Leadership of senior management & 0.925 & 3 & 2 & 0.703336 \\
\hline
\end{tabular}

Other roles that the government should do according to the respondents are providing a grant scheme for BIM training (the fourth most important factor with RII $=0.905$ ), conducting promotion and awareness road show about BIM (the fifth most important factor with RII $=0.892$ ) and giving tax reduction (the seventh most important factor with RII = 0.842). The respondents believe that by having a grant scheme for training and by giving tax reduction, they can increase the pace of implementing BIM. Previously, the Construction Industry Development Board (CIDB) has implemented this approach for contractors who implement Industrial Building System (IBS) in their construction projects [1] and this approach can also be used for those who are implementing BIM in their construction projects. This approach could attract the attention of construction players.

The government through its representative bodies such as CIDB could conduct awareness roadshow about BIM and promote the benefits of BIM. This promotion could spark the curiosity about BIM among construction players. By having a series of awareness programme to disseminate the knowledge of BIM, it can convey the benefits that can be gained by implementing BIM to the construction players. The private sector could take part in this promotion roadshow because involvements from private sector also play a significant role in speeding up the process of adoption and implementation of BIM in the Malaysian construction industry.

Besides the push from the government and BIM training program, leadership of senior management (the third most important factor with $\mathrm{RII}=0.925$ ) has a significant impact to accelerate the pace of BIM implementation in the Malaysian construction industry. Gilligan \& Kunz [25] found that the resistance to change from the senior management is one of the factors why some organisations are reluctant to utilise information technologies. Among their excuses are, to implement new technology they need to change their current organisational structure and process and it could jeopardise their productivities. This happens because the senior management do not really understand 
how to manage technological change. Having a strong support from senior management could ease the process of migration at any organisation, because this action shows the commitment of the organisation in adopting new technology and it will motivate their workers to implement it. O'Brien [16] revealed that, some people have low selfconfidence especially related with implementing new technology because the lack of knowledge, therefore motivation by the senior management could be one of the factors to build up self-confidence to motivate individuals to use new technology applications.

The respondents also believe that local universities could play a major role in promoting BIM by providing curriculum or course related to BIM, for example. This is why collaboration with universities (Research collaboration and curriculum designed for students) is one of the important factors that could increase the pace of implementing BIM with RII score of 0.879. Having a curriculum or course related to BIM could give the students an idea of what BIM is in the early stage and can produce students who are ready with $3 \mathrm{D}$ parametric model. As we know, BIM technology in Malaysia is really new, therefore there are many opportunities for university researchers to conduct research related to BIM and they could collaborate with the industry to identifying the needs and the area for exploration. Collaboration with local universities in research and development can be done through research grants which are provided by the government such as Exploratory Research Grant (ERGS) or Science Fund.

Fox \& Hietanen [31] added, one of the factors the organisations fail to realise about the benefit of implementing new technology is the lack of training provided by the organisation for their staff, and the level and type of training should be based on the needs of the organisation or individuals within an organisation. Training is one of the factors that could increase the pace in adopting new Information Technology (IT). In addition, Eastman et al. [9] found out, it is hard to guarantee that each person participating in the organisation has the required technology and skill; therefore, the organisation could establish a technical support group to cater these problems and to solve any problems arise. This technical support group could disseminate their knowledge among the staff within an organisation and this activity could spread the spirit of knowledge sharing among them. Therefore, the respondents believe that by outsourcing BIM specialist $(\mathrm{RII}=0.842)$ and having technical support team $(\mathrm{RII}=$ 0.800 ), it can complement the training program provided by the organisations.

\subsection{CONCLUSION}

Many evidence show that Building Information Modelling (BIM) can enhance the construction performance but the rate of implementation of BIM in the Malaysian construction industry has been at a slow pace. A number of factors that contributes to this situation are identified such as (1) Lack of knowledge about BIM, (2) Clients do not request/ enforce BIM and (3) Reluctance from clients, contractors or consultants to implement BIM. These issues need to be addressed accordingly if the government wants to see the Malaysian construction industry able to compete globally. Besides that, supports from the government also play a significant role to increase the pace of BIM implementation in the Malaysian construction industry. However, by just having a strong support from the government alone is not practical; therefore, the Malaysian construction players such as clients, consultants and contractors must play their own role by shifting the paradigm from using the traditional approach into a more innovative approach. To do this, the Malaysian construction industry needs the BIM implementation strategy and guide to ensure both parties: the government and the industry players work together to ensure the success in implementing BIM in Malaysia. It can be concluded that the construction industry in Malaysia needs to evolve by upgrading the current construction approach, whether in terms of practice, management or technology in order to meet the global standard.

\section{REFERENCES}

[1] CIDB, Construction Industry Review 1980-2009 (Q1). Construction Industry Development Board Malaysia. Kuala Lumpur, Malaysia, 2009.

[2] Zaini, B.O., Malaysian construction industry: challenges and demands. Key note address delivered on July 11 2000 in 3rd Annual Convention of Malaysian Structural Steel Association, Kuala Lumpur, 2000 in Abdul Razak Bin Ibrahim, Matthew H. Roy, Zafar Ahmed and Ghaffar Imtiaz. (2010). "An investigation of the status of the Malaysian construction industry", Benchmarking: An International Journal Vol. 17 No. 2, pp. 294-308, 2010.

[3] Alshawi S., Irani Z. and Baldwin L., "Benchmarking information technology investment and benefits extraction", Benchmarking: An International Journal, Vol. 10, No. 4, 414-423, 2003.

[4] Baldwin, A., Betts, M., Blundell, D., Hansen, K. L. and Thorpe, T., Measuring the benefits of IT innovation, in M Betts (ed.), Strategic management of IT in construction, Blackwell Science, Oxford, pp. 288-310, 1999. 
[5] Froese, T., Rankin, J. and Yu, K., "Project management applications, models and computer assisted construction planning in total project systems", Journal of Construction Information Technology, Vol. 5 No. 1, pp. 39-62, 1997.

[6] Mastura Jaafar, T. Ramayah and Abdul-Rashid AbdulAziz and Basri Saad, "Technology readiness among managers of Malaysian construction firms. Engineerin”, Construction and Architectural Management, Vol. 14 No. 2,pp. 180-191, 2007.

[7] Steward, R.A. and Mohamed, S., Integrated Information Resources: Impediments and Coping Strategies in Construction, Australian Centre for Construction Innovation, University of New South Wales, 2003.

[8] Revit, White Paper: The Five Fallacies of BIM, REVIT INC., 2008.

[9] Eastman, C., Teicholz, P., Sacks, R., and Liston, K., 2nd Edition BIM Handbook: A Guide to Building Information Modelling for Owner, Managers, Designers, Engineers, and Contractors, John Wiley and Sons, Inc. New Jersey, 2011.

[10] McGraw-Hill Construction, Building Information Modeling Trends Smart Market Report, McGraw-Hill, New York, 2008

[11] Taylor, J.E., \& Bernstein, P.G., "Paradigm trajectories of building information modelling practice in project networks". ASCE Journal of Management in Engineering, Vol. 25, No. 2, pp. 69-76, 2008.

[12] Kymmell, W., Building information modeling: Planning and managing construction projects with $4 D$ CAD and simulations, McGraw-Hill, New York, 2008.

[13] Khanzode, A., and Fisher, M. (2000). "Potential savings from standardized electronic information exchange: A case study for the steel structure of a medical office building". CIFE Technical Report, No 121. Palo Alto, CA: Stanford University.

[14] Azhar, S., Hein, M., and Sketo, B., "Building Information Modeling (BIM): Benefits, Risks and Challenges", Proceedings of the 44th ASC Annual Conference, Auburn, Alabama, April 2-5, 2008.

[15] Griffith, T. L., Zammuto, R. F. and Aiman-Smith, L., "Why New Technologies Fail: Overcoming the Invisibility of Implementation”, Industrial Management, Vol. 41, No. 3, pp. 29-34, 1999.

[16] O’Brien, W. J., “Implementation Issues In Project Web Sites: A Practitioner's Viewpoint", Journal of Management in Engineering, Vol. 16, No. 3, pp. 34-39, 2000.

[17] Whyte, J., Bouchlaghem, D. and Thorpe, T., "IT implementation in the construction organization", Engineering Construction and Architectural Management, Vol. 9 (5-6), pp. 371-377, 2002.
[18] Ruikar, K., Anumba, C.J. and Carrillo, P.M., "End-user perspectives on use of project extranets in construction organisations", Engineering, Construction and Architectural Management, Vol. 12 No. 3, pp. 222-35, 2005.

[19] Rojas, E.M. and Locsin, S., "Integrated practice: the road ahead", Proceedings of the 2007 ASCE Construction Research Congress, pp. 771-8, 2007.

[20] Martinko, M. J., Henry, J. W. and Zmud, R. W., “An attributional explanation of individual resistance to the introduction of information technologies in the workplace", Behaviour \& Information Technology, Vol. 15, No. 5, pp. 313-330, 1996.

[21] Khemlani, L. (2005), CORENET e-plan check: Singapore's automated code checking system, AECbytes, available at: http://www.aecbytes.com/ buildingthefuture/2005/CORENETePlanCheck.html

[22] Stephenson, P. and Blaza, S., "Implementing technological change in construction organisations", Proceedings of the IT in Construction in Africa conference, Mpumalunga, South Africa, 2001.

[23] Love, P. E. D., Irahi, Z., Li, H., Cheng, E. W. L. and Tse, R. Y. C., "An empirical analysis of the barriers to implementing e-commerce in small-medium sized construction contractors in the state of Victoria, Australia", Construction Innovation, Vol. 1, No. 1, pp. 31-41, 2001.

[24] Taylor, J.E., \& Levitt, R., "Innovation alignment and project network dynamics: An integrative model for change", Project Management Journal, Vol. 38, No3, pp. 22-35, 2007.

[25] Giligan, B., \& Kunz, J., VDC Use in 2007: Significant value, dramatic growth, and apparent business opportunity, CIFE Technical Rep. No TR171. Palo Alto, CA: Stanford University, 2007.

[26] Succar, B., "Building information modelling framework: A research and delivery foundation for industry stakeholders", Automation in Construction, Vol. 18, No. 3, pp. 357-375, 2010.

[27] Teo Ai Lin, Evelyn and Cheng Tai Fatt, "Building Smart A Strategy for Implementing BIM Solution in Singapore"; Synthesis Journal Singapore, 2006 available at: http:// www.itsc.org.sg/pdf/5_BIM.pdf.

[28] Lederer, A. L., Maupin, D. J., Sena, M. P. and Zhuang, Y., "The technology acceptance model and the World Wide Web", Decision Support Systems, Vol. 29, No. 3, pp. 269$282,2000$.

[29] Frey, L.R., Botan, C.H., Friedman, P.G., and Kreps, G.L., Investigating Communication: An introduction to Research Methods, Prentice Hall, 1991. 
[30] Frohlich, T. M., "Techniques for improving response rates in Operations Management Survey Research", Journal of Operations Management, Vol. 20, pp. 53-62, 2002.
[31] Fox, S., \& Hietanen, J., "Inter-organizational use of building information models: Potential for automation, informational and transformational effects", Construction Management and Economics, Vol. 25, pp. 289-296, 2007.

\section{PROFILES}

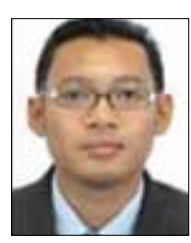

ZAHRIZAN ZAKARIA started his career as an Engineer for a contractor company for 5 years after obtaining his BEng (Hons) in Civil Engineering from Universiti Teknologi Malaysia (UTM) in 1999. He gained his Master Degree in Civil from Universiti Malaysia Pahang in 2007 and appointed as a lecturer at Faculty of Civil Engineering and Earth Resources, Universiti Malaysia Pahang (UMP) since then. Currently he was continuing his study at UMP at PhD level in the field of IT in construction focusing on Building Information Modelling. His research interest is within the area of Strategic Management of IT in Construction; Culture and organisational issues related to construction companies; Managing change and IT implementation; Social aspects of urban regeneration and sustainability.

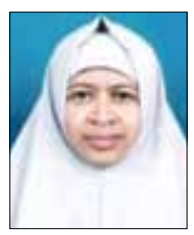

NASLY MOHAMED ALI was appointed as a Professor at the Faculty of Civil Engineering and Earth Resources, Universiti Malaysia Pahang (UMP) since 2003. Before she joins UMP, she was a professor at Faculty of Civil Engineering, Universiti Teknologi Malaysia (UTM). She obtained her Diploma in Civil Engineering from UTM in 1977. After graduated she appointed as Assistant Lecturer UTM. In 1980, she gained her first class BSc (Hons) Civil Engineering from University of Strathclyde. She was being offered to continue her study in $\mathrm{PhD}$ majoring in structural at University of Strathclyde and obtain her $\mathrm{PhD}$ in 1986. Because of her passion in information system, she enrols as a Master Degree student majoring in Information Technology Management at UTM and obtained her master degree in 2002. Her research interest and expertise are within the area of application of information systems for the construction application; managing change and IT implementation; Finite Elements; Structural dynamic (wind engineering and earthquake engineering) and prefabricated building construction.

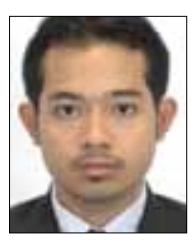

AHMAD TARMIZI HARON currently attached at the Faculty of Civil Engineering and Earth Resources, Universiti Malaysia Pahang (UMP) as a senior lecturer. He obtained her first degree in BEng (Hons) in Civil Engineering majoring in Construction Management from Universiti Teknologi Malaysia in 2003. After that he is pursuing his Master in Construction Management at Universiti Teknologi Malaysia and gained his Master Degree in 2005. After graduated from Universiti Teknologi Malaysia, he serves as lecturer at Universiti Malaysia Pahang from 2005 until 2007 before continue his study in PhD at University of Salford. He obtained his PhD in Building Information Modelling from University of Salford in 2013. His research interest and expertise are within the area of IT in construction, construction management, Culture and organisational issues related to construction companies; Managing change and IT implementation. He actives in involving with local construction working committee such as appointed by CIDB Malaysia as External Independent Reviewer for CIDB BIM Access Portal and as Research and Technical Committee for Building Information Modelling for Industrialised Building System which is appointed by CREAM CIDB Malaysia. 
AMANDA MARSHALL PONTING currently attached at the School of Built Environment, University of Salford as a senior lecturer. She obtained her first degree in BSc (Hons) in Applied Psychology from Liverpool John Moores University in 1999. She then gained her Master in Resources Informatics from University of Manchester in 2000 and her $\mathrm{PhD}$ in $\mathrm{nD}$ modelling from University of Salford in 2006. Her actives in many international working committees such developing Intel-City Roadmap Project and developing research links between the USA and the EU and funded by the NSF (National Science Foundation, USA). Her research interest and expertise are within the area of application of information systems in the Built Environment (GIS, VR, the internet, planning participation systems, multidimensional modelling); Culture and organisational issues related to construction companies; Managing change and IT implementation; Social aspects of urban regeneration and sustainability.

ZUHAIRI ABD. HAMID is the Executive Director of the Construction Research Institute of Malaysia (CREAM), a research institute established under the Construction Industry Development Board (CIDB) which he joined in January, 2006. He has over 27 years of experience in the construction industry and started his professional career as a civil and structural engineer with the Public Works Department of Malaysia in 1984. He has worked under various capacities such as a road, bridge, building and district engineer, assistant director of planning, and a forensic and structural design engineer. Later, in 1998 he joined CIDB as a senior manager at the Technology Development Division and was then appointed to his current post at CREAM. He holds a B.Eng. (Hons.) Civil from Universiti Teknologi Malaysia, a Masters Degree in Structural Dynamic Engineering from the Kanazawa University, Japan and a PhD in IT Construction majoring in Healthcare Facilities Management from the University of Salford, United Kingdom. He is a Professional Engineer (P.Eng.) in the Board of Engineers Malaysia, a Fellow of the Institution of Engineers, Malaysia (FIEM) and also sits as a Board Member in the United Nation support International Research Council, CIB "Conseil International du Bâtiment" (International Council for Research and Innovation in Building and Construction). He also serves as construction industry advisor to UTM, UTHM, UNITEN, UPNM and UiTM. 